\title{
KIPRAH DAKWAH BI AL-QALAM DAN BI AL-LISAN SYAIKH MUHAJIRIN AMSAR AL-DARY
}

\author{
Ahmad Khotib \\ STIT Almarhalah Al Ulya Bekasi \\ Email: ahmadkhotib180@gmail.com
}

\begin{abstract}
Abstrak
Artikel ini menemukan bahwa Sayikh Muhammad Muhadjirin Amsar alDary masuk dalam kategori pendakwah (muballigh) yang aktif berdakwah lewat media lisan dan tulisan. Hal ini terbukti dari banyaknya karya-karya tulis dalam bidang keagamaan yang beliau hasilkan semasa hidupnya. Selain itu, keikutsertaan Syaikh Muhajirin dalam dakwah lisan juga terbukti lewat pemikiran-pemikiran yang beliau lontarkan kala mengisi sebuah ceramah ataupun menanggapi sebuah permasalahan yang muncul di tengah masyarakat. Karya dan pemikiran yang beliau hasilkan dapat dikatakan telah mampu melakukan tugasnya untuk mengubah perspektif masyarakat awam tentang Islam dengan menawarkan pandanganpandangan beragam dari berbagai sudut pandang mazhab untuk memahami bahwa Islam adalah agama yang universal
\end{abstract}

Kata Kunci: Dakwah, Al-Qalam, Al-Lisan, Syaikh Muhajirin Amsar Al-Dary 


\section{Pendahuluan}

Dakwah selayaknya hidup selalu berjalan dinamis, ia tidak berhenti pada satu langkah lalu berhenti. Dakwah bukanlah perkara sekali habis, melainkan ia selalu mengikuti dan mengimbangi segala perkara dan persoalan yang terjadi dalam kehidupan manusia khususnya umat Muslim. Pada mulanya dakwah hanya dilakukan lewat lisan atau yang dalam Bahasa Arab dikenal dengan istilah dakwah bi al-lisan, apakah itu dari satu orang ke satu orang lainnya, maupun dari satu orang ke banyak orang. Akan tetapi, dalam perkembangannya sebagaimana tuntutan agar selalu salaras dengan kehiduoan manusia, dakwah mau tidak mau harus berinovasi. Berkembang dari yang semula hanya sebatas lisan merambah pada dunia tulisan. Tujuannya tak lain adalah agar dakwah dapat lebih bisa beradaptasi dalam upanya mengimbangi perubahan zaman. Merambahnya metode dakwah pada dunia tulisan dikenal dengan istilah dakwah bi al-qalam ataupun dakwah bi al-kitabah. Kedua istilah tersebut memiliki makna yang sama, akan tetapi dalam penggunaan kesehariannya, dakwah bi al-qalam lebih familiar dan sering digunakan untuk menggambarkan metode dakwah lewat dunia tulis menulis.

Dakwah dalam pengertian sederhana berarti menyampaikan pesan dan seruan kepada khalayak ramai untuk menjalankan perintah agama dan menjauhi apa-apa yang dilarang melalui berbagai media. ${ }^{1}$ Dakwah melalui tulisan adalah salah satu metode menyampaikan pesan yang melibatkan para sasaran dakwah menggunakan indera pengelihatan dan kemampuan membaca, ini tentu membawa konsekuensi pada segmen yang lebih terbatas pada masyarakat yang melek huruf maupun kalangan terpelajar saja. ${ }^{2}$ Karena itu sangat perlu diperhatikan kepada khalayak mana pesan dakwah akan ditujukan. ${ }^{3}$ Persoalan yang tidak kalah penting dalam upaya pengembangan dakwah melalui tulisan adalah media yang digunakan. Buku sebagai salah satu media dakwah untuk menyampaikan pesan-pesan dakwah masih memiliki keterbatasan, terutama karena segmen yang ditujunya tidak mencakup semua orang, melainkan terkotak-kotak pada segmen yang khusus seperti pelajar, pekerja, akademisi, dan masyarakat umum. Kerbatasan ini pada dasarnya diciptakan oleh biaya percetakan yang mahal, ketidakpraktisan beberapa buku cetak untuk dibawa ke mana-mana, tidak up to date-nya permasalahan yang dikaji dalam beberapa buku cetak, dan rendahnya minat masyarakat untuk membeli dan membaca buku. ${ }^{4}$ Walaupun begitu, media ini perlu digarap karena berbagai alasan seperti disebut di atas.

Seperti halnya dakwah bi al-lisan, pelaku yang terjun dalam praktik dakwah bi al-qalam juga haruslah mereka yang kompeten dalam bidangnya. Menguasai berbagai cabang ilmu-ilmu keislaman apakah itu yang bersentuhan dengan hukumhukum fiqh, hadith, balaghah, tasawuf, aqidah dan lain sebagainya. Pada masamasa awal turunnya Islam, dakwah secara tertulis dicontohkan langsung oleh

\footnotetext{
${ }^{1}$ Ahmad al-Hasyimi Bek, Mukhtaral-Ahadith al-Nabawiyyah, 1367 H /1948

${ }^{2}$ Husni Rahim, Arah Baru Pendidikan Islam (Jakarta: PT. Logos Wacana Ilmu, 2001), h. 147148.

${ }^{3}$ Geir Inge Orderud, "Is Trust a Driver for Territorially Embedded Industrial Systems? A Case Study of the Home-Building Industry in Norway," Geografiska Annaler, Series B, Human Geography, Vol. 89, No. 4 (2007), h. 341-359. http://www.jstor.org/stable/4621593 (Accessed: 25/02/2014).

${ }^{4}$ Mahmud Yunus, Pokok-pokok Pendidikan dan Pengajaran (Jakarta : Pustaka Mahmudin, 1960), h. 23.
} 
Rasulullah saw, ${ }^{5}$ sebabnya ia menjadi sunah yang harus dilakukan oleh segenap pekerja dakwah. Lebih dari itu, pembukuan al-Quran yang kini dikenal dengan sebutan mushaf, dalam perspektif jurnalistik adalah sebuah karya jurnalistik agung, berisikan wahyu dari Allah swt yang di dalamnya mencakup banyak sekali pemberitaan kepada umat manusia. ${ }^{6}$ Sebutan mushaf sendiri diambil dari kata dari șuhuf (kumpulan wahyu). Kata șuḥuf kemudian berkembang menjadi șah̆ifah yang berarti surat kabar maupun koran, dan șahāfi yang berarti wartawan atau jurnalis. ${ }^{7}$ Selain al-Quran, karya-karya ulama-ulama dan ahli ilmu terdahulu yang dikumpulkan dalam sebuah kitab (buku), termasuk kumpulan-kumpulan hadith Nabi seperti Șahīh al-Bukhārī dan Șahīh Muslim ${ }^{8}$ dapat pula dikategorikan sebagai sebuah karya jurnalistik.

Dalam konteks keindonesian khususnya Betawi, penyebaran Islam yang terjadi di Indonesia tidaklah terlepas dari peran para muballigh yang tak kenal lelah menyampaikan dakwah Islam ke berbagai penjuru Nusantara. Pada mulanya dakwah Islam disebarkan oleh para pedagang Muslim dari Gujarat, Arab dan India yang datang ke Indonesia. Metode yang digunakan pada masa itu masihlah metode klasik melalui penyampaian dengan lisan. Hal ini bisa dimaklumi dengan sebab masih sedikitnya kaum terpelajar yang bisa baca tulis di Nusantara kala itu. Akan tetapi, seiring dengan semakin menyebarnya dakwah Islam di Nusantara, pelajarpelajar yang menuntut ilmu agama dari para syaikh-syaikh yang datang dari berbagai penjuru dunia mulai berani melangkah lebih jauh dalam menuntut ilmu agama Islam. Hal ini ditandai dengan makin banyaknya kaum terpelajar Indonesia yang memutuskan menuntut ilmu agama ke Timur Tengah (Haramain). Semasa maupun sekembalinya dari Haramain, para pelajar ini banyak yang menuliskan kitab-kitab bernuansa agama apakah itu menggunakan Bahasa Arab sebagai kata pengantarnya, maupun menggunakan Arab Jawi dan Indonesia. Salah satu alumni Haramain yang cukup berpengaruh dalam pengembangan dakwah bi al-qalam di Indonesia khususnya di tanah Betawi adalah Syaikh Muhajirin Amsar al-Dary.

Tulisan dalam artikel ini akan secara khusus membahas tentang kehidupan Syaikh Muhajirin beserta kecintaannya akan ilmu pengetahuan agama, sebagaimana tertuang dalam banyak sekali kitab-kitab keagamaan dalam berbagai bidang ilmu hasil karya beliau sepanjang hidupnya. Karya-karya beliau sebagaimana tujuan ditulisnya karya tersebut adalah diperuntukkan sebagai bentuk dakwah bi al-qalam di tengah masyarakat, baik itu semasa beliau masih hidup maupun sesudah beliau wafat. Karya-karya itu juga diharapkan akan melahirkan karya-karya tulis lainnya dalam bidang keislaman dari penulis dan penuntut ilmu setelah beliau.

\section{Hasil dan Pembahasan}

${ }^{5}$ Salah satu bentuk dakwah bi al-qalam yang dilakukan Nabi saw pada masa awal penyebaran Islam adalah dengan mengirimkan surat ajakan masuk Islam kepada raja-raja non-muslim yang tersebar di seluruh penjuru Jazirah Arab. Lebih lanjut lihat, Bobby Rachman Santoso, Umul Baroroh dan Asep Dadang Abdullah, "Surat sebagai Media Dakwah: Studi atas Praktek Dakwah Rasullah saw terhadap Raja Heraclius, Kisra Abrawaiz, Muqouqis, dan Najasy," Jurnal Ilmu Dakwah, Vol. 35, No.1 (Januari - Juni 2015).

${ }^{6}$ Limmatus Sauda, "Etika Jurnalistik Perspektif al-Qur'an,” Jurnal Esensia, Vol. 15, No. 2 (September 2014), h. 164.

${ }^{7}$ Brannon M Wheller, Prophets in the Quran: An Introduction to the Quran and Muslim Exegesis (Oxford: Continuum Books, 2002), h. 5.

${ }^{8}$ Mahfudli Sahli, Etika Sexuil (Pekalongan : Bahagia, 1989), h. 13. 


\section{Biografi Singkat Syaikh Muhajirin dan Riwayat Keilmuannya}

Syaikh Muhammad Muhajirin Amsar al-Dary (selanjutnya disebut sebagai Syaikh Muhajirin saja) dilahirkan pada tanggal 10 November 1924 di Kampung Baru, Cakung, sebuah daerah di pinggiran kota Jakarta. Beliau adalah anak sulung dari pasangan $\mathrm{H}$. Amsar dan Hj. Zuhriah. ${ }^{9}$ Kedua orang tuanya, lahir dari silsilah keluarga besar dan berpengaruh di Kampung Baru. Bapaknya H. Amsar bin Fiin adalah keturunan keluarga pedagang dan ibunya $\mathrm{Hj}$. Zuhriah binti $\mathrm{H}$. Syafi'i bin Jirin bin Gendot adalah keturunan keluarga yang mencintai ilmu utamanya ilmuilmu agama. Begitu cintanya dengan ilmu agama, sehingga nama "Muhajirin" tersebut adalah penisbatan dari nama buyutnya yang alim yaitu Jirin. ${ }^{10}$ Syaikh Muhajirin mempunyai banyak sekali saudara, baik itu yang sekandung maupun yang seayah. Hal ini disebabkan oleh H. Amsar selaku ayah Syaikh Muhajirin mempunyai beberapa orang istri, yakni H. Zuriah, Kirom, Hofsah, dan Bono. Adapun saudara sekandung syaikh Muhajirin adalah Asenih, Saodah, Ma'ruf, Mahbub, Salmanih, dan Solahuddin. Sedangkan saudara seayah yaitu Saroja (Kirom), Barkah, Maqbulah, Asmaroh, Saroh, Rosyodi, Sodri (Hofsah), Naseh dan Soleh (Bono). Semasa kecil, Syaikh Muhajirin diasuh oleh kedua orangtuanya. Meskipun demikian, ia juga seringkali diasuh oleh kakak sepupunya dari jalur ibu yaitu Tiharoh.

Latar belakang kehidupan keluarga berpendidikan dari garis keturunan ibunya dan kecintaan luar biasa akan ilmu agama, menjadikan Syaikh Muhajirin sangat bersemangat mendatangi banyak sekali guru-guru agama diusianya yang masih tergolong muda. Hal ini terbukti dari sikap pantang menyerah Syaikh Muhajirin untuk terus mengayuh sepeda ontelnya tak peduli hujan panas dan berbagai rintangan alam lainnya demi mendatangi majelis-majelis ilmu yang tersebar di berbagai wilayah Jakarta seperti, Kwitang, Cipinang, hingga Pekojan. ${ }^{11}$ Seperti halnya batu keras yang terus menerus ditetesi air lama-kelamaan akan cekung juga, Syaikh Muhajirin pun tak ubahnya batu tersebut. Walau pada awalnya ia hanyalah anak yang biasa-biasa saja, tetapi dengan sikap pantang menyerahnya, Syaikh Muhajirin pada akhirnya tumbuh menjadi remaja dengan ilmu pengetahuan agama yang luas dan terus didera rasa haus akan ilmu bahkan sampai akhir hayat beliau.

Syaikh Muhajirin bisa dikatakan sangat beruntung memilki ibu yang sangat mendukung kehausannya akan ilmu. Tidak mengherankan jika kemudian sang ibunda rela menjual gelang kesayangannya sebagai modal Syaikh Muhajirin menuntut ilmu ke Timur Tengah, dengan harapan setelah pulang nanti, Syaikh Muhajirin akan menjadi ulama besar dan alim di seantero Betawi bahkan Nusantara. ${ }^{12}$ Harapan itu pun berbuah kenyataan, dengan keikhlasan doa seorang ibu serta kegigihan Syaikh Muhajirin dalam menuntut ilmu baik ketika beliau di Tanah Air maupun di Mekah dan Madinah, menjadikan beliau seorang yang mumpuni dalam berbagai kajian ilmu keislaman. Hal ini terbukti dari banyaknya karangan beliau dalam berbagai studi keislaman, serta kemampuan beliau dalam

\footnotetext{
${ }^{9}$ Majalah ALKISAH, No.12/14, edisi 17 (Juni 2007), h. 30.

${ }^{10}$ Muhammad Ali Wafa, Kiai Muhadjr Amsar; Mercusuar Hadis Nusantara, dalam Islam Nusantara Past and Present (Jakarta; Fakultas Adab dan Humaniora UIN Jakarta, 2014), h. 72.

${ }^{11}$ Muhammad Aiz, Biografi Syaikh KH. Muhammad Muhajirin Amsar Addary......, h. 8.

${ }^{12}$ Muhammad Ali Wafa, Kiai Muhadjr Amsar; Mercusuar Hadis Nusantara, dalam Islam Nusantara Past and Present....., h. 72.
} 
menjawab persoalan-persoalan agama yang dilontarkan oleh para ulama di tempat tinggalnya.

Pendidikan agama yang dijalani beliau semasa hidupnya dapat dibagi dalam dua fase besar yaitu fase ketika menuntut ilmu di tanah air dan fase ketika menuntut ilmu di Haramain. Selama menuntut ilmu di tanah air, Syaikh Muhajirin berguru kepada banyak sekali alim ulama ahli ilmu, guru-guru beliau tersebut adalah sebagai berikut; Guru Asmat, ${ }^{13}$ KH. Abdul Manaf al-Mukhayyar, ${ }^{14}$ K.H. Saleh Ma'mun al-Bantani, ${ }^{15}$ KH. Ahmad, KH. Hasbiyallah Klender, KH. Anwar, K. H. Hasan Murtaha, Syekh Muhammad Tahir K. H. Ahmad bin Muhammad, Syekh Abdul Majid, dan al-Sayid Ali bin Abdurrahman al-Habsy. Adapun guru-guru beliau selama menuntut ilmu di Haramain adalah sebagai berikut: Syekh Abdul Ghani Jamal, Syekh Muhammad Ahyad, Syekh Muhammad al-Masyat, Syekh Zaini Bawean, Syekh Muhammad bin Husain al-Maliki, Syekh Mukhtar Ampetan, Syekh Muhammad al-'Arabi al-Tubbani al-Sutayfi al-Jazairi, Syekh Said 'Alawi Abbas al-Maliki, Syekh Ibrahim Fathani, Syekh Muhammad amin al-Kutbi, Syekh Muhammad Amin al-Singiti, dan Syekh Abdul Rahman al-Afriqi

Kamis tanggal 19 Shafar 1375 H, bertepatan dengan 6 Agustus 1955, Syaikh Muhajirin tiba di tanah air, setelah sebelumnya mendapat surat dari ibunda beliau yang isinya tidak lain meminta beliau pulang. Dengan perenungan dan pertimbangan yang matang, akhirnya beliau memenuhi panggilan orang tuanya. ${ }^{16}$ Keberkahan dari guru-guru beliau dan konsistensinya dalam mengamalkan ilmu menjadikan beliau pribadi yang kharismatik di hadapan santri-santrinya, di mana beliau sebagai mudhir memiliki peran yang sangat penting dalam perkembangannya mendirikan dan membangun pondok pesantren (rubat) yang beliau beri nama Annida al-Islamy.

\section{Karya dan Keistimewaan Syaikh Muhajirin dalam Bidang Akademik}

Syaikh Muhajirin adalah salah satu ulama yang produktif dalam menulis. ${ }^{17}$ Sebab menulis merupakan tradisi ulama dan intelektual Muslim. Tradisi ini

13 Ahmad bin Kuncung atau yang kemudian lebih dikenal dengan sebutan Guru Asmat Cakung adalah salah seorang ulama besar Betawi yang sangat diakui keluasan ilmunya dan menjadi guru bagi banyak ulama-ulama besar Betawi di kemudian hari seperti; Kyai Muhammad Muhajirin Amsar al-Dary, Mu'allim Rasyid, KH. Abdullah Azhari, KH. Badruddin, dan KH. Murtaqi. Lebih lanjut lihat, https://www.zawiyahjakarta.or.id/2019/09/24/guru-asmat/

${ }^{14} \mathrm{KH}$. Abdul Manaf al-Mukhayyar adalah seorang ulama besar Betawi yang sangat disegani dan dihormati. Beliau juga sekaligus menjadi sosok yang sangat berperan besar dalam pembangunan Darunnajah, di mana beliau bukan hanya sebagai penggagas, tetapi juga sebagai wakif. Ia juga membelanjakan hartanya untuk menggaji guru, membelanjakan uangnya untuk membangun madrasah, dan menutup biaya operasional pada saat awal mula pendirian pesantren ini. Abdul Manaf juga penggagas ide pendirian lembaga pendidikan yang mengajarkan agama Islam dan mencetak kader-kader ulama. Lihat, https://www.zawiyahjakarta.or.id/2019/09/24/kh-abdul-manafmukhayyar/

${ }^{15}$ Syaikh Muhammad Muhajirin, Sejarah Singkat....., h. 20.

${ }^{16}$ Syaikh Muhammad Muhajirin, Sejarah Singkat....., h. 10.

17 Seorang sahabat, Ali bin Abi Thalib pernah berkata; "Ikatlah ilmu dengan menuliskannya". Hal ini patut menjadi sebuah renungan akan pentingnya menuangkan ilmu dan pengetahuan kedalam bentuk tulisan. Ilmu yang hanya disimpan dalam otak pemiliknya saja, akan berakhir setelah kematian pemilik ilmu itu. Tetapi ilmu yang diikat (ditulis) kedalam bentuk buku, ia akan tetap bermanfaat bahkan setelah pemilik buku itu telah tiada. "Mengikat ilmu" memiliki kemanfaatan yang jauh lebih besar, karena kemanfaatannya dapat melintasi ruang dan waktu. Hal ini sesuai dengan sabda Rasulallah yang menyatakan ada tiga perkara yang tidak akan terputus pahalanya, salah satunya adalah ilmu yang bermanfa'at. Lihat Badiatul Muchlisin, Berdakwah dengan Menulis Buku (Bandung: Media Qalbu, 2004), h. 39-40. 
merupakan konsekuensi logis dari dorongan Islam yang sangat menekankan arti penting penguasaan ilmu dalam kehidupan. Beliau telah mengarang lebih dari tiga puluh delapan kitab, semuanya berbahasa Arab. Yang paling terkenal kitab Miṣbāh al-Zalām, delapan jilid. Karya-karya beliau merupakan kitab yang wajib dibaca oleh para santri, mulai dari tingkat Madrasah Tsanawiyah sampai tingkat alMarhalah al-'Ulya (setingkat strata satu).

Karangan-karangan beliau dimaksudkan untuk memberikan kemudahan kepada santri-santri Pondok Pesantren Annida al-Islamy dalam mengkaji berbagai disiplin ilmu-ilmu keislaman adalah bentuk nyata dari cara berfikir beliau yang mengedepankan nilai-nilai kekinian, ketika masyarakat mulai memiliki animo untuk menyukai buku sebagai sumber ilmu dan pengetahuan maka hal tersebut bisa dijadikan alternatif yang cukup representatif. Kegigihan, ketegasan dan kesabaran beliau dalam mendidik santri, telah melahirkan banyak ulama besar yang juga mumpuni dalam membaca dan mengamalkan kitab-kitab yang beliau ajarkan. Adapun daftar karya-karya Syekh Muhammad Muhajirin adalah sebagai berikut:

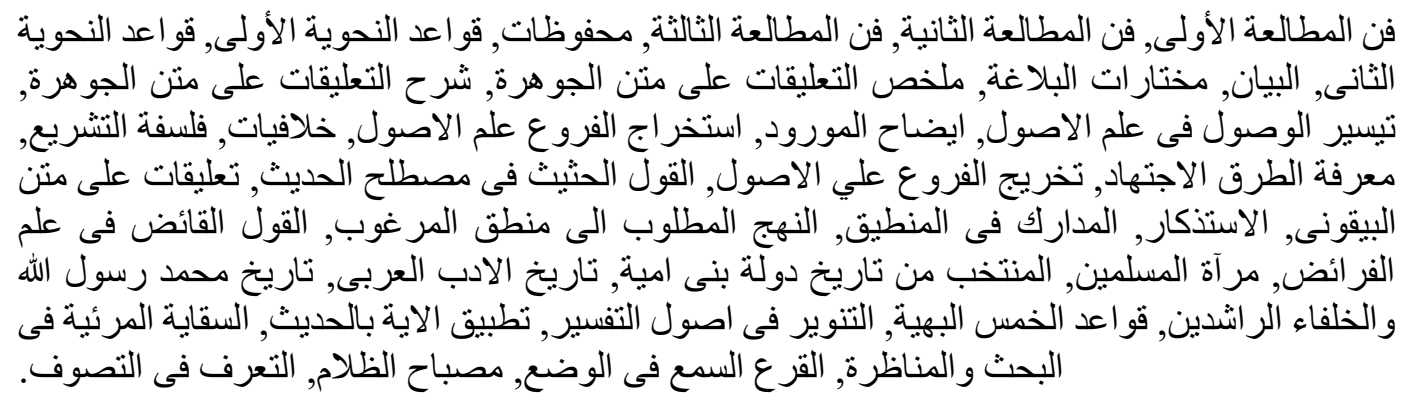

Banyaknya karya yang dihasilkan Syaikh Muhajirin memperlihatkan berkah belajar dan mengajar yang selama itu ia jalani. Di samping karya-karya di atas, berkah tersendiri adalah banyak dari murid Syaikh Muhajirin yang menjadi ulama, di antaranya KH. Mahfuzh Asirun, KH. Syarifuddin Abdul Ghani, KH. Alwi Zein, KH. Kamal Yusuf, KH. Zamakhsyari dan banyak lainnya yang tak bisa disebut satu persatu. Tak hanya berjaya dalam menuntut ilmu, kepribadian Syaikh Muhajirin juga dikenal sangat baik dan bersahaja. Meskipun dikenal sebagai ulama prolifik dalam berbagai disiplin ilmu keislaman, Syaikh Muhajirin merupakan sosok yang konsisten untuk terus mendidik dan belajar. Karya yang dimilikinya sebanyak 34 kitab tidak menyulutkan dirinya untuk terus belajar dan mendidik masyarakat. Sikap bersahaja yang ingin terus mengajar di tengah masyarakat ini ternyata telah tampak ketika beliau masih muda.

Pada tahun 1950-an, salah seorang santri beliau yang berasal dari Malaysia pernah menawarkan Syaikh Muhajirin saat masih lajang untuk menduduki posisi tinggi Mufti Malaysia, tetapi tawaran tersebut ditolak dengan tegas. Alasan penolakan tersebut, karena beliau masih betah ingin belajar dan mengajar di Mekah kala itu. Hal berbeda terjadi saat ibunya yang meminta Syaikh Muhajirin untuk kembali ke tanah air, beliau tidak bisa menolak permintaan tersebut. Beliau menyadari tidak ada yang mampu menandingi panggilan orang tua, terlebih ibu, sebab ibunya menjadi salah satu orang paling berpengaruh di di kehidupan Syaikh Muhajirin. Fragmen kisah ini penulis nukil dari salah satu muridnya Fachruddin, 
yang beliau pernah dikisahkan oleh Muhajirin saat ta'lim di pengajian subuh di pesantren Annida al-Islamy. ${ }^{18}$

Keteguhan dan konsistensi Syaikh Muhajirin dalam belajar dan mengajar merupakan buah dari pendidikannya di masa muda. Di antara buah pendidikan tersebut, Muhajirin Amsar memiliki Sanad keilmuan yang jelas dari guru-gurunya. Sanad yang dimiliki Syaikh Muhajirin merupakan bentuk relasi yang kuat dan intim antara guru dan murid. Banyaknya karya yang dihasilkan oleh Syaikh Muhajirin Amsar merupakan hasil belajar selama lebih kurang 9 (sembilan) tahun menimba ilmu di Haramain. Setiap kitab yang ditulis merupakan representasi sanad keilmuan yang diperolehnya selama proses belajar tersebut. Selama mengabdikan diri untuk ilmu dan mengajar masyarakat, beliau banyak menimba ilmu dari pengalaman belajar mengajar selama hidupnya.

Banyaknya karya tulis yang dihasilkan oleh Syaikh Muhajirin semasa hidupnya, secara tidak langsung menunjukkan kualitas keilmuan beliau yang mumpuni dan terpercaya dalam berbagai bidang ilmu keislaman. Rentetan karya dan kualitas keilmuan yang beliau tunjukkan semasa hidupnya, kemudian menunjukkan kepada khalayak ramai baik yang bersinggungan dengan dunia pendidikan maupun pembelajaran awam akan keistimewaan-keistimewaan yang beliau miliki semasa hidup, khususnya dalam bidang akademik. Berikut akan dijabarkan beberapa keistimewaan dalam bidang akademik yang beliau miliki semasa hidup.

\section{Ilmu Hadith}

Berbicara mengenai perkembangan ilmu hadith di Indonesia tentu tidaklah lengkap pabila tidak menyertakan nama Syaikh Muhammad Muhajirin Amsar alDary. Keluasaan ilmu yang dimiliki Syaikh Muhajirin dalam bidang hadith sudah tidak perlu lagi diragukan keabsahannya. Salah satu kitab beliau yang cukup monumental dan menjadi rujukan bagi para akademisi hadith di Indonesia adalah kitab Miṣbāḥ al-Ẓalām fi Syarh Bulūgh al-Marām Min Adillah al-Ahkām yang terdiri dari empat jilid. Sebagaimana judulnya, kitab Miṣbāh al-Zalām merupakan syarh (penjelas) bagi kitab Bulūgh al-Marām karya Ibnu Hajar al-Asqlani. Sebagai salah satu karya dalam bidang ilmu hadith terbesar di Indonesia, kitab Miṣbāh alZalām menghadirkan ritme tersendiri baik dari segi penulisan maupun metodologi yang digunakan dalam membahas sebuah hadith.

Sebagai pembelajar yang sangat tekun dalam bidang keilmuan Islam, khususnya hadith, tidak mengeherankan jika kemudian Syaikh Muhajirin memiliki keistimewaan-keistimewaan tersendiri yang tidak dimiliki pembelajar lainnya. Salah satu di antara keistimewaan Syaikh Muhajirin adalah jalur keilmuan dan mata rantai pendidikan yang diperolehnya. Dalam tradisi keilmuan Islam, istilah sanad/mata rantai sangat penting, sebab hal ini merujuk kepada pandangan bahwa ilmu itu diwariskan dari satu generasi ke generasi. Sanad yang jelas dipahami banyak ulama sebagai hal terpenting dalam mencari ilmu. Legitimasi sanad keilmuan tidak saja untuk memperkuat pemahaman yang didapat dari seorang guru, akan tetapi juga sebagai ketersambungan, keilmuan dari guru-guru sebelumnya. Legitimasi sanad itu sendiri sesuai dengan sabda Nabi saw, "Innama al- 'ulamā'u warasah al-anbiy $\bar{a} . " 19$

\footnotetext{
18 www.muidkijakarta.or.id

${ }^{19}$ Berikut hadis lengkapnya :
} 
Dalam sanad keilmuan Syaikh Muhajirin terdapat beberapa guru yang memberikan ijazah kitab Bulügh al-Marām. Berikut mata rantai sanad kitab Bulüg al-Marām yang diperoleh oleh Muhajirin Amsar adalah dari Syekh Muhamamd Yasin al-Fadani, dari Syekh Muhamamd Yasin bin Ali Muhammad al-Makky, dari Sayyid Abi Maliki Syatha Bakar al-Makky, dari Sayyid Ahmad bin Zaini Dahlan, dari Usman bin Hasan Dimyathi, dari Abdullah bin Syarqawi Hijazi, dari Muhammad bin Salim al-Ziyadi, dari Syekh Muhammad bin al-'Ala al-Babily, dari Salim bin Muhammad al-Nahuri, dari al-Najm Muhammad Ahmad al-Ghaitiy, dari Zakariyah bin Muhammad al-Anshari, Ibnu Hajar al-Asqalani. ${ }^{20}$

Dari rentetan mata rantai ini Syaikh Muhajirin memperoleh otoritas terhadap kitab Bulūg al-Marām dan melakukan syarah atas kitab tersebut. Bagi beberapa kalangan, seorang ulama memiliki nilai lebih dalam menyampaikan pengajian dan pendidikan Islam lainnya jika memiliki sanad keilmuan yang jelas. Pandangan serupa juga diperoleh dari para berbagai penganut tariqah Islam. Jalur keilmuan dalam tariqah semuanya terhubung kepada Sayyidina Ali bin Abi Thalib hingga Nabi Muhammad saw. Legitimasi sanad tariqah ini sangat penting bagi eksistensi dari berbagai macam tariqah sehingga akan sangat sesuai dengan jalur tempuh yang telah dibuka oleh para mursyid. Urgensi mata rantai keilmuan ini pada dasarnya lahir dari tradisi keilmuan hadith, pelacakan sanad berfungsi sebagai validitas perkataan Nabi, sahabat, tabi'in dan seterusnya, dengan demikian mata rantai ilmu yang jelas bagi para ulama sangatlah urgen. Hal ini senada dengan pendapat Ibnu al-Mubarak (132 H), Ibnu Sholah (506 H), al-Nawawi (578 H) dan lain-lainnya. ${ }^{21}$

\section{Ilmu Falak}

Ketertarikan Syaikh Muhajirin terhadap ilmu falak sudah dimulai semenjak beliau muda. Guru yang pertama kali mengajarkan Syaikh Muhajirin tentang ilmu falak adalah KH. Ahmad bin Muhammad, murid dari Syekh Mansur al-Falaky. Kepadanya beliau mempelajari ilmu-ilmu astronomi meliputi gerhana bulan dan matahari. Kecintaan dan minat belliau yang besar untuk mengetahui fenomena alam yang berkaitan dengan ilmu astronomi, menjadikan beliau tidak hanya menyimpan ilmu itu untuk dirinya sendiri, akan tetapi mengajarkannya pula pada murid-murid beliau di perguruan Annida al-Islamy Bekasi.

Selain KH. Ahmad bin Muhammad, Syaikh Muhajirin juga berguru pada banyak ulama lainnya untuk memperdalam pengetahuan beliau berkaitan dengan ilmu falak. Di antara guru-guru yang pernah beliau datangi seperti; Guru Muhammad Manshur bin Abdul Hamid, Salah satu murid Guru Muhammad Manshur yang tidak diketahui namanya, Guru Abdul Majid, Syaikh Muhammad Yasin al-Falaki, dan beberapa ulama di Tanah Suci Mekkah yang tidak disebutkan namanya. Adapun kitab-kitab berkaitan dengan ilmu falak yang beliau pelajari

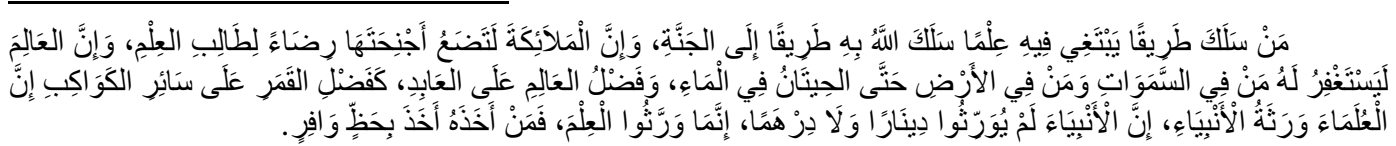

Hadis ini diriwayatkan banyak ahli hadith. Di antaranya Hasan al-Tirmidzi, Sunan al-

Tirmidzi, Vol. 4 (Beirut: Dar al-Gharbi al-Islami, 1998), h. 346. Abu Daud, Sunan Abi Daud, Vol. 3 (Beirut: Maktabah al-Ishriyah, 1999), h. 317. Ibnu Hibban, Shahih Ibn Hibban, Vol. 1 (Beirut: Muassis al-Risalah, 2003),

${ }^{20}$ Muhammad Muhajirin Amsar al-Dary, Misbāh al-Zalām, 6. Untuk lebih jelasnya lihat daftar tabel silsilah sanad kitab Misbāh al-Zalām Syarh Bulug al-Maram.

${ }^{21}$ Al-Suyuthi, Tadrib al-Rawi (Beirut: Dar al-Kutub al-Ilmiyah, 2009), h. 15; Ibnu Sholah, Muqaddimah Ibn Sholah....., h. 17. Muhy al-Din al-Nawawi, Kifayat al-Riwayah....., h. 12. 
antara lain adalah: Matan Wașilah al-Țullab, Risalah Rub'ul Mujayyab, Risalah Mulakhas, Sulam al-Nirain, serta Ijtima'dan Gerhana.

Keilmuan yang mumpuni dan kekonsistenan yang Syaikh Muhajirin tunjukkan dalam bidang ilmu falak termasuk membangun lajnah falakiyah Cakung, menjadikan beliau dan hasil pengamatan astronomi yang dilakukan oleh timnya sebagai salah satu rujukan kredibel utamanya dalam menentukan masuknya Ramadhan dan Syawal. Begitu pentingnya ilmu falak sehingga berkembang begitu pesat dengan memunculkan berbagai macam metodologi yang saling mendukung dan melengkapi. Ilmu falak saat ini tidak hanya "milik" umat Islam saja namun telah menjadi pusat perhatian seluruh umat beragama. Hal ini dikarenakan begitu pentingnya kedudukan dan manfaat ilmu tersebut.

Sebagaimana telah diketahui bersama bahwa secara garis besar Ilmu Falak terbagi atas dua metodologi utama, yakni berdasarkan hisab dan ru'yah. Kedua metodologi tersebut sejak puluhan bahkan ratusan tahun yang lalu telah menjadi kekuatan yang sangat dahsyat di bidang keilmuan karena telah diikuti atau diyakini oleh jutaan manusia. Meskipun demikian secara prinsip kedua metodologi tersebut (hisab dan ru'yah) tidak dapat dikatakan bertentangan namun justru saling melengkapi. Syaikh Muhadjirin sendiri merupakan salah satu sosok ulama Betawi yang memiliki perhatian terhadap keberadaan ilmu falak, baik metodologi hisab maupun ru'yah.

Pelaksanaan ru'yah di Cakung dimulai sejak tahun 1936 yang dipimpin langsung oleh Syaikh Muhajirin. Mulai tahun 1947 pelaksanaan ru'yah diteruskan oleh murid-murid beliau yang tidak lain merupakan adik-adik sepupu beliau, yaitu KH. Abdul Hamid, KH. Abdul Halim, KH. Abdullah Azhari, KH. Abdul Salam. Pemindahtugasan ini disebabkan Syaikh Muhadjirin memutuskan untuk berdiam di Mekkah guna menuntut ilmu. Pada awalnya pelaksanaan ru'yah di Cakung hanya dilaksanakan sebanyak 6 kali setiap tahunnya, mulai bulan Rajab hingga Dzulhijjah. Namun apabila dianggap perlu pelaksanaan ru'yah pernah dilakukan setiap bulannya selama 7 tahun berturut-turut.

Pada tahun 1950, penerus Syeikh Muhammad Muhadjirin, yakni KH. Abdul Hamid, KH. Abdullah Azhari, dan KH. Abdul Salam berhasil melihat hilal awal bulan Syawal dengan ketinggian dua derajat. Hasil ru'yah tersebut kemudian disyahkan oleh Pengadilan Agama Bekasi untuk diitsbat, setelah terlebih dahulu dilakukan pemeriksaan terhadap ketiga peru'yah tersebut. Tahun 1958, KH. Abdul Hamid, KH. Abdul Halim, dan KH. Abdul Salam berhasil melihat hilal awal bulan Dzulhijjah pada ketinggian 2,25 derajat. Hasil ru'yah tersebut disyahkan oleh Pengadilan Agama Jawa Barat. Berdasarkan hal tersebut KH. Zuber memasukkan kejadian tersebut ke dalam buku karangannya yang berjudul "al-Khulashah alWafiyah".22

Pada tahun 1960, KH. Abdul Hamid dan kawan-kawan dengan disaksikan oleh KH. Hasbiallah dan KH. Sobri yang merupakan utusan dari Pengadilan Agama Jawa Barat serta KH. Asli Junaidi, berhasil melihat hilal dengan ketinggian 4 derajat. Pada saat itu terjadi kejadian yang luar biasa, dimana terjadi perubahan cuaca yang sangat cepat dari mendung tiba-tiba menjadi terang sehingga ru'yah dapat dilakukan. Pada tahun 1991, delegasi ulama Malaysia yang terdiri dari ahli fiqih dan ahli hisab yang dipimpin oleh Prof. Dr. H. Abdul Hamid Abdul Majid berkunjung ke Indonesia untuk memperoleh penjelasan tentang pelaksanaan ru'yah

\footnotetext{
${ }^{22}$ http://annidaalislamy.ac.id/manaqib-pendiri-mahad
} 
hilal di Indonesia. Pengadilan Agama Bekasi memfasilitasi pertemuan antara delegasi Malaysia tersebut dengan ulama Jakarta Timur dan Bekasi, bertempat di Masjid al-Makmur, Klender.

Menurut delegasi Malaysia tersebut, selama ini dalam menetapkan awal Ramadhan, Idul Fitri dan Idul Adha mereka selalu mengikuti Mekkah. Di Malaysia sendiri sebenarnya ada 28 lokasi ru'yah, namun baru berhasil 2 kali dengan ketinggian 8 derajat. Setelah berakhirnya pertemuan tersebut, pimpinan delegasi Malaysia tersebut menyatakan untuk mengikuti Indonesia dalam menetapkan awal Ramadhan, Syawal dan 10 Dzulhijjah. Dalam kitab Miṣbāh al-Zalām juz ke 3 halaman 187-188 dikatakan bahwa, "hilal mungkin saja terlihat tanpa harus mencapai ketinggian 7 derajat atau lebih." Hal ini pernah terjadi di Mekkah saat beliau berada di kota tersebut.

Pelaksanaan ru'yah hilal yang dilakukan oleh lajnah falakiyah Cakung hingga saat ini masih terus berlanjut, meski Syaikh Muhajirin sebagai pendiri lembaga tersebut telah lama berpulang ke Rahmatullah. Meski tanpa Syaikh Muhajirin di antara mereka, penerus masih menjaga warisan keilmuan beliau dengan tetap menjalankan pelaksanaan rru'yah sesuai dengan pedoman dan petunjuk yang telah diajarkan oleh Syaikh Muhajirin. Di antara penerusnya adalah KH. Ahmad Syafi' 'i, Lc. Putra dari KH. Abdul Hamid serta salah seorang koleganya yang bernama KH. Yazid. Saat ini mereka berdua tetap aktif melakukan ru'yah hilal serta membimbing murid-muridnya di Cakung Jakarta Timur.

\section{Ilmu Balagah}

Bidang keilmuan lainnya yang menjadikan Syaikh Muhajirin istimewa adalah keluasaan ilmu yang beliau miliki dalam bidang balagah. Hal ini terbukti dari dua buku karangan beliau tentang ilmu balagah yang mencakup pula di dalamnya pemahaman terhadap ilmu bayan serta dan segala macam yang berkaitan dengan balagah. Kedua buku tersebut adalah al-Bayān yang dipelajari di tingkat Tsanawiyah Pondok Pesantren Annida al-Islamy Bekasi dan al-Mukhtārāt alBalāghah yang dipelajari di tingkat Aliyah.

\section{Ilmu Bahasa}

Syaikh Muhajirin semasa hidupnya lebih terkenal sebagai ulama hadith dan fiqih yang banyak membahas hadith-hadith ahkam. Meski begitu, tidak sedikit buku-buku berkaitan dengan ilmu bahasa yang berhasil dikarang oleh beliau, yang mana hal ini menunjukkan keluasan ilmu beliau. Dari 34 kitab karya Syaikh Muhajirin, enam di antaranya membahas tentang ilmu bahasa mulai dari tingkat dasar sampai mahir. Keenam buku tersebut adalah sebagai berikut: Fannu alMuţāla'ah al-Ulā, Fannu al-Muţāla'ah al-Thān̄i, Fannu al-Muțāla'ah alThalāthah, al-MahfüZ̄āt, Qawā'id al-Nahwwiyah al-Ulā, dan Qawā'id al-Nahwiyah al-Thānī. Keenam kitab tersebut merupakan buku wajib yang harus dipelajari semua siswa tingkat Tsanawiyah di Pondok Pesantren Annida al-Islamy Bekasi.

\section{Ilmu Ushul al-Fiqh}

Selain penguasaan yang mumpuni akan ilmu bahasa, Syaikh Muhajirin juga terkenal akan keistimewaan dan kedalaman ilmunya dalam bidang ushul fiqh. Hal ini tentunya tidaklah mengherankan mengingat Syaikh Muhajirin menaruh perhatian yang sangat besar terhadap hukum-hukum syar'i apakah itu yang bersumber dari al-Qur'an, hadith, maupun ijtihad para ulama. Pembahasan tentang ushul fiqh menjadi karya dengan jumlah terbanyak yang pernah ditulis oleh Syaikh Muhajirin yaitu tujuh kitab. Berbeda dari kitab-kitab lainnya yang hampir seluruhnya dipelajari di tinkat Tsanawiah dan Aliyah, khusus untuk kitab-kitab 
yang membahas tentang ushul fiqh hanya dipelari di tingkat perguruan tinggi, yaitu di Majma' al-Marhalah al- 'Ulya yang masih berada di bawah Yayasan Pondok Pesantren Annida al-Islamy Bekasi.

Berbicara tentang keistimewaan-keistimewaan yang dimiliki Syaikh Muhajirin utamanya dalam bidang ilmu-ilmu agama sesungguhnya tidak akan ada habisnya. Beberapa poin yang disebutkan di atas hanyalah sebahagian kecil dari apa yang menjadikan beliau sebagai salah satu ulama Nusantara khususnya Betawi, yang sangat dihormati dan diakui penguasaan keilmuannya. Beberapa bidang keilmuan lain yang juga turut menjadi perhatian Syaikh Muhajirin adalah sejarah, tauhid, ushul hadith, tafsir, tasawuf, qawaid fiqh, dan masih banyak lagi. Selain mengekalkan ilmu dalam bentuk tulisan yang tersusun dalam berjilid-jilid buku karangan beliau, Syaikh Muhajirin juga terkenal dengan perilakunya yang santun namun tegas. Ketegasan beliau tidak hanya ditunjukkan kepada anak-anak dan keluarga beliau saja, tetapi juga terhadap semua elemen yang memiliki keterkaitan dengan beliau.

Sisi lain yang juga merupakan keunikan dan keistimewaan Syaikh Muhajirin adalah jiwa seni beliau yang cukup kuat. Ketertarikan beliau untuk mempelajari bait maupun syair Arab dapat dilihat dalam satu mata pelajaran yang ditetapkan beliau untuk tingkat Aliyah, yaitu ilmu 'Arudh. Tak hanya itu, di antara sekian banyak buku-buku beliau yang berkonsentrasi pada bidang keilmuan Islam, terdapat satu kitab yang berbeda dari kitab-kitab lainnya. Kitab tersebut adalah Asmā al-Kitāb, yang berisikan tentang puisi dan syair-syair. Kurikulum pembelajaran ilmu arudh sendiri ditujukan untuk memberikan siswa pemahaman akan berbagai model syair maupun puisi-puisi Arab. Contoh lain yang tak kalah menarik dari ketertarikan Syaikh Muhajirin terhadap seni adalah keberhasilan beliau dalam menciptakan hymne Pondok Pesantren Annida al-Islamy dan juga Majma' al-Marhalah al-'Ulya Bekasi.

\section{Kiprah Dakwah dan Sumbangan Pemikiran Syaikh Muhajirin dalam Kehidupan Sosial}

Sebagai ulama yang telah melewati banyak sekali tantangan dan rintangan semasa hidupnya, baik itu yang bersinggungan dengan permasalahan-permasalahan keagamaan, maupun yang bersinggungan dengan masyarakat, admistrasi dan politik, Syaikh Muhajirin tampil sebagai ulama yang bukan saja berbicara tentang hadith-hadith, hukum syarh, aqidah akhlak, tasawuf, dan lain sebagainya yang memiliki keterkaitan dengan permasalahan keagamaan. Tetapi beliau juga sangat peka terhadap permasalahan-permasalahan yang bersinggungan dengan kehidupan sosial, sekalipun dasarnya tetap disandarkan pada agama. Beberapa konsep pemikiran yang pernah dikemukakan beliau baik ketika memberikan ceramah di hadapan audience, maupun yang terlihat dari cara beliau mendidik dan menghadapi suatu permasalahan akan dijabarkan sebagai berikut:

\section{Pendidikan}

Berbicara tentang pendidikan tentunya bukanlah hal yang asing bagi Syaikh Muhajirin, utamanya bila dilihat dari silsilah keluarrga beliau terlebih dari garis keturunan ibundanya yang sangat memprioritaskan pendidikan melebihi banyak aspek-aspek kehidupan lainnya. Sebagai seorang santri, akademisi, dan penuntut ilmu yang pantang menyerah, Syaikh Muhajirin memiliki pemikiran yang sangat terbuka dalam dalam memajukan dunia pendidikan. Hal ini bias dilihat dari kinerja beliau dalam membangun dan mengembangkan institusi pendidikan dari tingkat dasar hingga perguruan tinggi, yang di dalamnya bukan hanya diisi oleh 
pembelajaran-pembelajaran berkaitan dengan ilmu-ilmu agama saja, tetapi juga mencakup ilmu-ilmu sains dan humaniora lainnya.

Cabang pendidikan lain yang didirikan oleh Syaikh Muhajirin yang juga tak kalah penting untuk dikembangkan adalah kelompok pengajian khusus ibu-ibu dan taman Pendidikan al-Qur'an yang dikhususkan bagi anak-anak yang tinggal di sekitar Pondok Pesantren Annida al-Islamy Bekasi. ${ }^{23}$ Konsentrasi beliau yang sangat besar bagi dunia pendidikan tentu saja tidak terlepas dari kegemaran beliau mengajar. Hal ini bias dibuktikan dengan masih tetap aktifnya beliau mengisi kajian-kajian dan mengajar bahkan hingga mendekati akhir hayat beliau.

Jika dirunut secara berturut, partisipasi beliau dalam mengembangkan dunia pendidikan di Indonesia khususnya di wilayah Bekasi dimulai sejak kembalinya beliau dari tugas menuntut ilmu di Arab Saudi. Partisipasi beliau menjadi lebih konsern pada dunia pendidikan formal yang bernaung di bawah sebuah institusi pasca menikah dengan istrinya Hannah binti KH. Abdurrahman bin Mu'allim Shodri, yang mana merupakan pendiri Pondok Pesantren Bahagia yang berlokasi di Bekasi. Keikutsertaan beliau sebagai menantu KH. Abdurrahman dalam mengembangkan Pondok Pesantren Bahagia tentulah tidak selalu berjalan dengan mulus. Ada banyak sekali rintangan yang harus dihadapi, termasuk di dalamnya ketika Pondok Pesantren Bahagia harus dirubuhkan sebab adanya perluasan markas Kodim TNI yang kebetulan lokasinya bersebelahan dengan pesantren. ${ }^{24}$

Keadaan terpaksa yang menjadikan Pondok Pesantren Bahagia harus pindah lokasi juga kemudian menimbulkan masalah lainnya di kalangan internal pesantren. Persoalan ini kemudian mencapai kesepakatan bahwa santri-santri yang ada dibebaskan untuk memilih akan mengikuti guru yang mana sesuai dengan kata hati masing-masing. Hal ini yang kemudian menjadi cikal bakal berdirinya Pondok Pesantren Annida al-Islamy Bekasi, sebab sebagian besar santri yang ada di Pondok Pesantren Bahagia memilih untuk mengikuti Syaikh Muhajirin karena dianggap memiliki ikatan yang dekat dengan santri dan wawasan keilmuan yang sangat luas.

Pada masa-masa awal bendirinya Pondok Pesantren Annida al-Islamy, setelah melalui banyak sekali proses panjang yang menyita waktu dan tenaga, masyarakat menititipkan anak-anak mereka ke pesantren tanpa memikirkan embelembel ijazah dan administrasi-admistrasi formal lainnya. Para orangtua hanya berharap agar anak-anak mereka mendapatkan pendidikan agama yang baik dan benar sehingga dapat menjadi tumpuan kuat bagi mereka dalam menjalani kehidupan di masa mendatang.

Berdasar pada pandangan jauh ke depan dan kebutuhan para murid yang mulai menuntut adanya sertifikat legal yang diakui pemeritah sebagai penanda selesainya suatu jenjang pendidikan, atas instruksi Syaikh Muhajirin pada akhir tahun 70-an, secara resmi Pondok Pesantren Annida al-Islamy mulai melakukan penyetaraan dengan sistem pemerintah dengan mengikuti ujian nasional. Pada waktu, Pondok Pesantren Annida al-Islamy belum melakukan ujian nasional secara mandiri, melainkan masih menginduk pada beberapa instansi pendidikan lainnya seperti Madrasah Aliyah Negeri Subang. ${ }^{25}$

23 Muhammad Aiz, Biografi Muhammad Muhajirin Amsar Addary: Pendiri Pondok Pesantren Annida al-Islamy Bekasi (Bekasi: al-Hanin Press, 2019), h. 43-44.

${ }^{24}$ Muhammad Aiz, Biografi Muhammad Muhajirin Amsar Addary ........ h. 26.

${ }^{25}$ Muhammad Aiz, Biografi Muhammad Muhajirin Amsar Addary........ h. 44. 
Seiring berjalannya waktu, lembaga pendidikan Islam Pondok Pesantren Annida al-Islamy Bekasi berkembang pesat menjadi sebuah lembaga Pendidikan yang cukup diperhitungkan di wilayah Bekasi. Kondisi ini tidak hanya karena didorong oleh sumber daya manusia yang kredibel mencakup para guru, pengurus, dan jajaran lain yang terkait dengan jalannya pesantren, tetapi juga diuntungkan oleh keberadaannya yang sangat dengan jantung kota dan pusat pemerintahan Bekasi. Merasa tidak puas dengan pencapaian beliau dengan berkembangnya Pondok Pesantren Annida al-Islamy, pada tahun 1984 secara resmi dibukalah sekolah lanjutan yang diberi nama Majma' al-Marhalah al-'Ulya, yang kurikulumnya $^{26}$ disusun dan dikembangkan sendiri oleh Syaikh Muhajirin berdasarkan pada pengalaman beliau selama menuntut ilmu di Arab Saudi.

Konsep Majma' al-Marhalah al- 'Ulya tidak ubahnya dengan konsep pendidikan pesantren, hanya saja tingkatannya lebih atas dan materi-materi yang dijarkan juga tentunya lebih bervariasi dan tinggi dibanding dengan jenjang-jenjang pendidikan sebelumnya. Pada awal mulanya, pendirian perguruan tinggi ini dimaksudkan bagi santri-santri Pondok Pesantren Annida al-Islamy Bekasi yang ingin melanjutkan ke jenjang pendidikan tinggi namun masih ingin berada dalam lingkup suasana pesantren. Dalam perkembangannya, mahasiswa yang belajar di perguruan tinggi ini bukan hanya mereka yang base-nya lulusan Pondok Pesantren Annida al-Islamy Bekasi, tetapi juga yang dari luar itu. Materi yang diajarkan di perguruan tinggi ini juga bukan lagi melulu kajian agama tetapi juga telah merambah pada kompetensi akademik dalam bidang non-agama.

Pemikiran Syaikh Muhajirin yang sangat mengerti akan pentingnya pendidikan, bukan hanya berpengaruh pada lembaga-lembaga pendidikan yang yang dikelola oleh beliau, tetapi juga pada pola pendidikan yang beliau terapkan pada anak-anaknya. Latar belakangan pendidikan Islam yang kuat yang dimiliki beliau, tidak menjadikan Syaikh Muhajirin menjadi sosok yang otoriter terhadap jalur pendidikan yang ingin ditempuh oleh anak-anaknya khususnya anak laki-laki. Sikap demokrasi dan keterbukaaan beliau tampak dari cara beliau membebaskan anak-anak laki-lakinya untuk mempelajari bidang ilmu apa saja termasuk bidangbidang keilmuan umum yang tidak bersinggungan dengan agama.

Kebebasan yang diberikan Syaikh Muhajirin pada anak-anak laki-lakinya justru berkebalikan dengan sikap beliau yang sangat tegas dalam menentukan pendidikan bagi anak-anak perempuannya. Anak-anak perempuan Syaikh Muhajirin tidak diperkenankan untuk melanjutkan pendidikan ke jenjang perguruan tinggi kecuali hanya di Majma' al-Marhalah al- 'Ulya yang notabenenya masih berada di lingkungan pondok pesantren Annida al-Islamy. Sikap tegas ini bukan tidak mendapat protes dari anak-anak perempuan beliau, tetapi ketegasan dan sikap beliau tidak dapat digoyahkan yang menjadikan anak-anak perempuan beliau memilih manut terhadap aturan beliau. ${ }^{27}$

Ketekunan dan minat Syaikh Muhajirin yang besar akan majunya dunia pendidikan bukan hanya dibuktikan dari segi fisik banyaknya alumni yang pernah belajar di Pondok Pesantren Annida al-Islamy Bekasi, tetapi juga dibuktikan dari pola pembelajaran yang tidak terpaku pada aspek kognitif saja, melainkan juga

26 Kurikulum Majma' al-Marhalah al-'Ulya tidak lagi mengajarkan materi kitab yang bersumber dari madzhab Syafi'i. Hal ini disebabkan materi tersebut telah diajarkan di tingkat Madrasah Aliyah. Lebih lanjut lihat, Muhammad Aiz, Biografi Muhammad Muhajirin Amsar Addary......., h. 45.

${ }^{27}$ Muhammad Aiz, Biografi Muhammad Muhajirin Amsar Addary......., h. 61. 
terpenuhi dari aspek spiritual, psikomotorik dan afektifnya. Dalam rangka memenuhi aspek-aspek tersebut, Syaikh Muhajirin tidak lelah mencontohkan halhal baik yang terus menerus secara konsisten beliau lakukan, seperti shalat berjamaah, mengisi kajian dan forum-forum keagamaan baik di lingkungan pesantren maupun di majelis-majelis taklim yang tersebar di wilayah Bekasi dan Jakarta, serta memberikan wejangan-wejangan yang pasti bermanfaat bagi kehidupan banyak orang di masa depan.

\section{Politik Praktis}

Pernikahan yang dijalani Syaikh Muhajirin dengan Hannah binti KH. Abdurrahman, secara tidak langsung menyeret Syaikh Muhajirin pada pusaran politik praktis yang selama masa Orde Baru sangat besar gaungnya. Sayangnya, keberadaan sang mertua sebagai salah satu kader muda partai Masyumi yang cukup diperhitungkan, tidak lantas menjadikan Syaikh Muhajirin silau untuk turut serta dalam gegap gempita politik saat itu. ${ }^{28}$ Seperti pada masa sebelum keberangkatan beliau untuk menimba ilmu di Tanah Suci, bukan sedikit tawaran yang meminta belaiu untuk mengambil bagian dalam gempita politik saat itu. Namun keteguhan belaiu untuk tetap menuntut ilmu menjadikan semua tawaran-tawaran posisi tersebut ditolak oleh Syaikh Muhajirin.

Penolakan yang dilakukan Syaikh Muhajirin dan keputusan yang bulat untuk tetap berangkat menimba ilmu ke Tanah Suci di tengah gempuran Agresi Militer Belanda II di Indonesia, menciptakan nada-nada miring yang menuduh beliau tidak cinta terhadap NKRI dan hanya ingin melarikan diri dari kewajiban perang membela tanah dan rakyat Indonesia. Dengan tidak menghiraukan tuduhantuduhan miring yang mengarah kepadanya, Syaikh Muhajirin dari sebelum berangkat ke Tanah Suci sampai sekembalinya beliau, bahkan hingga akhir hayatnya tetap teguh pada pendirian untuk tidak bersangkut-paut dengan sistem politik praktis sekalipun kesempatan yang bisa beliau dapatkan sangat terbuka lebar.

Keengganan Syaikh Muhajirin untuk masuk dalam ranah politik praktis hingga akhir hayatnya, tidak hanya menjadi bahan kajian bagi para santri-santri yang pernah menimba ilmu kepada beliau, tetapi juga menjadi penasbihan akan keteguhan hati beliau untuk tetap berada di jalur pendidikan tanpa berpihak pada golongan dan partai politik manapun. Biasnya batas antara posisi sebagai ulama, agama, pendidikan, dan politik ketika seorang tokoh agama meleburkan dirinya dalam ruang politik menjadi salah satu alasan besar keengganan beliau untuk berpolitik. Hal ini dapat dilihat dari sikap beliau yang tidak berubah sekalipun terdapat banyak sekali perkara-perkara politik yang diseret ke ranah agama maupun sebaliknya. $^{29}$

Keengganan Syaikh Muhajirin untuk melebur dalam politik praktis juga terlihat dari hubungan beliau yang cenderung biasa-biasa dengan para stakeholder yang memerintah di daerah Bekasi. Meski begitu, sebagai bentuk rasa hormat dan menghargai terhadap pemerintah, Syaikh Muhajirin selalu mengundang para pemangku-pemangku kekuasaan di wilayah Bekasi untuk ikut serta dalam acaraacara yang diselenggarakan oleh Pondok Pesantren Annida al-Islamy Bekasi. Berkebalikan dengan pemerintah yang hampir secara rutin hadir dalam acara-acara yang diselenggarakan oleh pesantren, Syaikh Muhajirin secara pribadi justru sangat

\footnotetext{
${ }^{28}$ Muhammad Aiz, Biografi Muhammad Muhajirin Amsar Addary ......., h. 51.

${ }^{29}$ Muhammad Aiz, Biografi Muhammad Muhajirin Amsar Addary........ h. 52.
} 
jarang menghadiri acara-acara baik formal maupun informal yang diselenggarakan oleh pemerintah. Alasan terbesar yang beliau kemukakan adalah kesibukan jadwal mengajar sehingga tidak tersisa waktu beliau untuk mendatangi acara-acara tersebut, kecuali jika acara tersebut secara kebetulan tidak bersamaan dengan waktu beliau mengajar. ${ }^{30}$

Salah satu bukti keteguhan prinsip yang dijunjung tinggi oleh Syaikh Muhajirin adalah pada saat penetapan 1 Ramadhan maupun 1 Syawal. Sekalipun pemerintah dengan jejeran Menteri dan tim ahlinya telah melakukan ru'yatul hilal dan disepakati bersama untuk diterapkan secara nasional, Syaikh Muhajirin lebih memilih untuk mengikuti penetapan 1 Ramadhan maupun Syawal bersandar pada hasil pengamatan beliau dan tim lajnah falakiyahnya. ${ }^{31}$ Alasan lain yang juga tak kalah penting sebagaimana diaungkapkan oleh beliau adalah perlunya ulama untuk bersikap independen dan netral. Sebab kedekatan ulama dengan dunia politik dan pemerintah atau sampai melebur di dalamnya, sangat mungkin akan menimbulkan presenden negatif terhadap kenetralan dan cara berpikir ulama tersebut ketika berhadapan dengan sebuah masalah. ${ }^{32}$

\section{Organisasi Keagamaan}

Keberagaman wajah Islam di Indonesia tidak luput menjadi bahan pemikiran Syaikh Muhajirin. Keberadaan Syaikh Muhajirin sebagai tokoh agama yang memiliki pengalaman keilmuan dalam bidang yang luas di tengah kehidupan Muslim Indonesia yang multikultur, tentunya menjadi sorotan tersendiri bagi para murid maupun masyarakat sekitar yang sering bersinggungan secara sosial dengan beliau. Syaikh Muhajirin dalam kehidupannya seringkali dituduh sebagai penyebar paham Wahabi. Tuduhan ini berhembus bukan tanpa alasan, masyarakat yang notabenenya masih sangat awam dengan pemahaman-pemaham agama melihat sekilas dari cara beragama yang dilakukan Syaikh Muhajirin berseberangan dengan praktik keberagamaan yang lumrah dilakukan di masyarakat Bekasi dan Indonesia pada umumnya.

Posisi Syaikh Muhajirin yang merupakan salah seorang alumni dari Ummul Quro Madinah menjadi salah satu alasan paling kuat maraknya tuduhan beliau sebagai pengikut Wahabi. Hal ini pada dasarnya bisa dimaklumi sebab Arab Saudi sendiri merupakan negara yang menganut paham tersebut. Alasan-alasan lain yang muncul adalah sebab absennya beliau dari melakukan perayaan maulid nabi. Tiadanya perayaan maulid nabi di Pondok Pesantren Annida al-Islamy Bekasi menguatkan stigma masyarakat bahwa Syaikh Muhajirin adalah sosok yang tidak mencintai "zurriah" Rasulullah saw. Menepis tuduhan tersebut, Syaikh Muhajirin kepada murid-muridnya selalu menyampaikan bahwa beliau sangat mencintai Rasullah saw dan para zurriahnya.

Kecintaan itu dibuktikan dengan kegemaran beliau mempelajari hal-hal yang berkaitan dengan Rasulullah dan keluarganya beserta ajaran-ajaran yang dibawa Rasulullah saw. ${ }^{33}$ Bagi Syaikh Muhajirin, perayaan maulid nabi bukan hanya sebatas pembacaan al-Barzanjī, Simts al-Durar, al-Dībā', dan Sharaf alAnām. Lebih dari itu, dengan mengkaji ajaran-ajaran Rasulullah yang terkandung dalam berbagai kitab serta memuliakan zurriah Rasulullah yang masih ada, adalah

\footnotetext{
${ }^{30}$ Muhammad Aiz, Biografi Muhammad Muhajirin Amsar Addary......., h. 54.

${ }^{31}$ Muhammad Aiz, Biografi Muhammad Muhajirin Amsar Addary......., h. 52.

${ }^{32}$ Muhammad Aiz, Biografi Muhammad Muhajirin Amsar Addary ........ h. 54.

${ }^{33}$ Muhammad Aiz, Biografi Muhammad Muhajirin Amsar Addary ........ h. 48.
} 
merupakan penghormatan dan tanda cinta yang sangat besar kepada Rasulullah dan segenap anak-anak cucunya. ${ }^{34}$

Menyoal kembali pada perkara organisasi keagamaan yang diikuti oleh Syaikh Muhajirin, pernah suatu ketika beliau ditanya oleh salah seorang muridnya berkaitan dengan hal tersebut; "Pak Kyai, Islam-nya NU atau Muhammadiyah?" jawaban yang kemudian diberikan Syaikh Muhajirin adalah; "Islam saya adalah Islam là Ilāha illa Allah wa Muhammad Rasūlullah." ${ }^{35}$ Hal ini merupakan suatu yang patut jadi bahan pemikiran, bahwa keberadaan NU dan Muhammadiyah sebagai salah satu organisasi keagamaan terbesar di Indonesia tidak lantas membuat Syaikh Muhajirin terjebak dalam pusaran diskursus yang tak kunjung usai di antara keduanya.

Syaikh Muhajirin memilih untuk berdiri di atas apa yang beliau yakini dan pahami sebagaimana telah beliau pelajari selama bertahun-tahun ke banyak guru dan kitab. Namun, apa yang dipahami oleh beliau tidak selamanya dapat dipahami dan dimengerti oleh masyarakat luas khususnya yang masih sangat awam pemahaman agamanya. Hal inilah yang kemudian menimbulkan riak bahwa Syaikh Muhajirin merupakan bagian dari kelompok Wahabi. Di luar segala kontroversi dan anggapan yang beredar berkaitan dengan pola keberislaman beliau, Syaikh Muhajirin sepanjang hidup sampai akhir hayatnya sangat menjunjung tinggi paham ahlu sunnah wa al-jamaah dalam pelaksanaan ibadah sehari-harinya.

\section{Politik Identitas}

Kondisi Indonesia pada masa-masa awal kemerdekaan hingga pergantian tampuk kekuasaan di tahun 1960-an masih sangat didominasi perasaan kesukuan maupun kedaerahan yang tinggi. Konsep "putra daerah" merupakan salah satu isu paling banyak dihembuskan untuk membedakaan perlakuan antara putra daerah asli dengan yang bukan. Tidak hanya keengganan Syaikh Muhajirin untuk terlibat dalam kancah politik praktis maupun menjadi salah satu bagian dari dua ormas Islam terbesar di Indonesia, integritas Syaikh Muhajirin dalam berdakwah juga diuji dengan isu putra daerah. Sebagai individu yang lahir di daerah Kampung Baru Cakung (saat itu belum masuk wilayah Bekasi), Syaikh Muhajirin dianggap sebagai pendatang yang sudah seharusnya menghormati dan mendahulukan keberadaan ulama-ulama yang memiliki garis keturunan sebagai putra daerah asli Bekasi.

Persoalan isu kedaerahan ini merambat pada wilayah agama. Hal ini didasari pada ketidakcocokan antara Syaikh Muhajirin dengan beberapa oknum ulama yang secara kebetulan lahir dan besar di Bekasi. Ketidaksukaan yang dibumbui dengan isu putra daerah terhadap Syaikh Muhajirin menjadi sebuah senjata yang cukup ampuh untuk mengintimidasi beliau dalam berdakwah. Beberapa kondisi yang kerap ditemui beliau selama mendakwahkan Islam di tanah Bekasi dengan label "bukan putra daerah," seringkali berupa kekerasan fisik dan tak jarang juga berupa kiriman santet dari orang-orang yang notabenenya juga mengerti agama. ${ }^{36}$

Persoalan berkaiatan dengan isu "putra daerah" juga berimbas pada kegiatan pengajaran dan majelis taklim yang diasuh oleh beliau di beberapa daerah, khususnya yang paling berat daerah Tambun dan Cikarang. Kesulitan yang didapatkan dalam berdakwah mengembangkan syiar Islam di kedua daerah tersebut

\footnotetext{
${ }^{34}$ Muhammad Aiz, Biografi Muhammad Muhajirin Amsar Addary........ h. 49.

${ }^{35}$ Muhammad Aiz, Biografi Muhammad Muhajirin Amsar Addary ........ h. 42.

${ }^{36}$ Muhammad Aiz, Biografi Muhammad Muhajirin Amsar Addary........ h. 55.
} 
bukanlah disebabkan oleh beratnya pertanyaan-pertanyaan yang diajukan kepada beliau, namun lebih disebabkan oleh segelintir orang yang tidak menyukai beliau. Di mana segelintir orang tersebut tega mengutus orang gila untuk menjadi makmum shalat, yang selanjutnya dengan ganas membacok Syaikh Muhajirin dengan senjata tajam. Tidak berhenti di situ, bentuk terror lain yang juga didapatkan Syaikh Muhajirin sebagai akibat dari isu "putra daerah" adalah ditabrak dengan sepeda motor hingga mengakibatkan beliau terluka. ${ }^{37}$

Selain itu, seringkali pengajian yang seharusnya diisi oleh Syaikh Muhajirin dibubarkan secara sepihak oleh kelompok-kelompok tertentu yang tidak menyukai beliau. Ada saja alasan yang dikemukakan orang-orang ini kepada jamaah agar mereka meninggalkan majelis seperti, Syaikh Muhajirin sedang sakit sehingga tidak bisa mengisi kajian seperti biasanya, ataupun beliau sedang ada urusan yang tidak bisa ditinggalkan. Sebagaimana halnya manusia biasa yang memiliki keterbatasan pertahan fisik, salah satu kiriman santet yang cukup menyita tenaga dan kesehatan beliau menjadikan Syaikh Muhajirin harus pasrah menjalani penyakit tanpa bisa melakukan kegiatan apa-apa selama dua tahun lamanya. Meskipun pada akhirnya Syaikh Muhajirin mengetahui siapa yang tega mengirimkan santet kepadanya, beliau tetap bersabar dan tidak membalas perbuatan orang tersebut, apalagi menggembar-gemborkan Namanya agar diketahui khalayak ramai. ${ }^{38}$

\section{Demokrasi}

Berbicara tentang demokrasi, Syaikh Muhajirin memiliki pandangan tersendiri yang kemudian beliau terapkan kepada seluruh murid-murid yang pernah berguru kepada beliau. Bagi Syaikh Muhajirin demokrasi berarti setiap orang berhak untuk mendapatkan pembelajaran dan mengeksperisan dirinya, menggapai mimpi-mimpinya tanpa didikte ataupun didoktrin, melainkan lebih pada memberi wawasan dan pandangan-pandangan agar setiap siswa mampu memikirkan hal-hal baik apa yang seharusnya mereka lakukakan di masa depan. Salah satu bentuk prinsip demokrat beliau adalah dengan tidak memaksakan murid-muridnya untuk menjadi seperti apa yang beliau perintahkan, melainkan memberi mereka kebebasan untuk mengembangkan keilmuannya dalam bidang apa saja termasuk dengan mendirikan pesantren-pesantren Islam dengan tanpa harus membawa-bawa label Syaikh Muhajirin maupun Annida al-Islamy Bekasi. ${ }^{39}$

\section{Jihad}

Pemaknaan kata jihad dalam Islam pada dasarnya memiliki banyak sekali versi. Seringkali jihad disalahartikan sebagai sebuah pembenaran untuk melakukan kejahatan, pembunuhan, aniaya dan lain sebagainya atas nama membela hak-hak agama. Pemahaman ini tentu saja pada akhirnya menimbulkan paradigma negative terhadap Islam yang tak jarang berujung pada sebutan Islam teroris. Sebagai seorang yang sepanjang hidupnya bergumul dalam dunia akademik, Syaikh Muhajirin memiliki pandangan tersendiri berkaitan dengan penerjemahan kata jihad. Bagi Syaikh Muhajirin, di era berkembang seperti sekarang ini, jihad sudah seharusnya tidak lagi dipahami sebatas senjata perang baik secara fisik maupun ideologi. Dalam pandangan beliau, jihad yang tak kalah penting dan urgennya

\footnotetext{
${ }^{37}$ Muhammad Aiz, Biografi Muhammad Muhajirin Amsar Addary......., h. 58.

${ }^{38}$ Muhammad Aiz, Biografi Muhammad Muhajirin Amsar Addary........ h. 56.

${ }^{39}$ Muhammad Aiz, Biografi Muhammad Muhajirin Amsar Addary ........ h. 50.
} 
adalah jihad melalui pendidikan dengan menyebarkan pesan-pesan kebaikan, kegamaan, semangat, kedamaian, akhlak al-karimah, dan lain sebagainya. ${ }^{40}$

Kegigihan Syaikh Muhajirin untuk berjihad dalam bidang pendidikan tidak pernah surut sekalipun beliau menghadapi banyak sekali rintangan dan cobaan. Rintangan-rintangan tersebut adakalanya berupa kondisi kesehatan beliau yang memburuk, gosip-gosip miring yang beredar berkaitan dengan paham keislaman beliau, mazhab yang beliau ikuti, termasuk juga di dalamnya keengganan beliau untuk berada dalam jarak yang cukup dekat dengan politik dan pemerintah. Selain melaksanakan tugasnya sebagai pengajar, jihad yang dilakukan Syaikh Muhajirin juga berupa kegigihannya dalam menulis kitab-kitab yang berkaitan dengan studi keagamaan seperti fiqh, aqidah, tafsir, bahasa, hadith, dan lain sebagainya. Tidaklah mengherankan juga kemudian terdapat premis yang menyatakan bahwa, "Tintanya ulama lebih berharga daripada darahnya para syuhada." ${ }^{41}$

\section{Prinsip Syaikh Muhajirin dalam Pengembangan Dakwah bi al-Qalam}

Besarnya peranan dakwah bi al-qalam dalam membuka wawasan berpikir dan mengubah pola kehidupan social masyarakat luas, pada akhirnya memunculkan pertanyaan sederhana tentang seberapa besar peranan para Syaikh, ulama, maupun akademisi dengan karya-karya mereka dalam pengembangan metode dakwah bi alqalam, yang secara khusus dalam konteks ini ditujukan kepada Syaikh Muhajirin. Dengan kurang lebih 34 karya tulis sepanjang hidupnya, Syaikh Muhajirin bukan saja menjadi ulama yang terkenal akan ketawadukan dan kesederhanaannya, tetapi beliau juga menempati posisi tinggi sebagai salah satu ulama paling produktif dalam menghasilkan karya tulis yang pernah dimiliki Betawi. ${ }^{42}$

Ketekunan dan semangat beliau yang tinggi dalam menghasilkan karya tulis menunjukkan sikap hidupnya yang sepenuhnya didedikasikan kepada berkembangnya ilmu pengetahuan, khususnya dalam bidang keagamaan. Bagi beliau, menulis bukan hanya sebagai metode paling ampuh dan kekal untuk mentransfer ilmu, tetapi menulis juga merupakan pembuktian diri dan sebagai bentuk khidmat kepada guru-guru beliau, baik di dalam maupun di Haramain. Kitab Miṣbāh al-Zalām sebagai magnum opus dari keseluruhan karya yang pernah beliau tulis, menjadi salah satu kitab hadith paling banyak dirujuk para pegiat ilmu hadith baik dari segi isi maupun metode penulisan dan penyarahan yang beliau gunakan.

Kitab Miṣbāh al-Zalām pulalah yang membawa Syaikh Muhajirin masuk dalam daftar penting ulama dengan kontribusi paling berpengaruh dalam disiplin ilmu hadith khususnya dalam pengembangan syarh hadith di Indonesia. Penggunaan metode muqārin (perbandingan) dalam upaya penyarahan hadith sebagaimana yang dilakukan Syaikh Muhajirin, merupakan suatu metode yang langka (bisa dibilang satu-satunya) digunakan para pegiat ilmu hadith di Indonesia yang kebanyakannya menggunakan metode tahlili (global) dan ijmali (analitis). Dipilihnya metode muqārin dalam menyarah hadith-hadith yang terdapat dalam kitab Bulūgh al-Marām didasarkan pada kondisi sosial masyarakat Indonesia yang tercipta dari berbagai suku, budaya, dan agama. Bahkan, dalam agama Islam yang

${ }^{40}$ Muhammad Aiz, Biografi Muhammad Muhajirin Amsar Addary......., h. 59.

${ }^{41}$ Muhammad Aiz, Biografi Muhammad Muhajirin Amsar Addary......., h. 59.

${ }^{42}$ Rakhmat Zailani Kiki, dkk., Genealogi Intelektual Ulama Betawi, (Jakarta: JIC, 2010), h. 
dianut masyarakat Indonesia terdapat beragam ideologi yang diikuti berdasarkan pada organisasi keagamaan mana yang mereka ikuti.

Salah satu tujuan utama dari penggunaan metode muqārin adalah untuk memberikan wawasan luas bagi masyarakat Indonesia khususnya umat Muslim, agar lebih berhati-hati dan berpikir matang dengan membaca dari segala sudut pandang ketika berhadapan dengan suatu masalah. Maraknya ideologi Islam radikal di Indonesia juga menjadi salah satu alasan utama digunakannya metode muqārin dalam penulisan kitab Mișbāh al-Zalām. Dengan dipaparkannya beragam pandangan yang berbeda-beda dari berbagai sudut pandang mazhab, diharapkan dapat memperkecil resiko timbulnya pertikaian-pertikaian akibat perbedaan pandangan dalam menyikapi sebuah masalah.

Sebab permasalahan-permasalahan utama yang berkaitan dengan tradisi dan hukum baik itu hukum syariah maupun hukum perdata sangatlah rentan konflik. Pemahaman yang luas terhadap suatu hukum dengan memahami secara detail perbedaan pendapat dari masing-masing madzhab, tentu mengantarkan pembaca untuk lebih bersikap toleran dan dinamis. Sebab ia tidak mudah mengklaim kafir, khurafat dan lainnya kepada umat Muslim yang berbeda dengannya. Selain itu, umat muslim Indonesia juga lebih mudah dan fleksibel dalam menyelesaikan suatu persoalan hukum. Karena pokok dari suatu permasalahan tersebut dapat di'illatkan dengan pendapat para ahli hukum melalui kaidah ushul fikih. Syaikh Muhajirin memiliki prinsip yang kuat dalam memahami hadith khususnya hadith ahkām. Ia menyadari bahwa masyarakat Indonesia mulai mengembangkan pola nalarnya dengan meninggalkan pendapat ulama-ulama klasik. Sedangkan sebagian lagi bersikap taklid terhadap suatu imam madzhab tertentu, sehingga menimbulkan kejumudan dan sikap statis terhadap hukum utamanya hukum-hukum furu'iyyah. Syaikh Muhajirin menyadari perlu adanya keseimbangan dalam memahami hukum Islam yang tersirat dalam hadith-hadith Nabi saw. Perlu adanya multi-pemahaman terhadap hadith Nabi saw. yaitu melalui pemahaman luas tehadap hukum lintas madzhab.

Syaikh Muhajirin juga menyajikan paparan terkait pandangan para ulama dengan tidak melakukan klaim terhadap pendapat tertentu. Jika terjadi persoalan yang kompleks ia akan mengambil kaidah ushul fikih sebagai upaya ijtihadnya, dan mengatakan pendapat ulama yang satu lebih kuat dibanding ulama lainnya. Terminologi aqwā (lebih kuat) ia gunakan sebagai upaya tahqīq terhadap ijtihadnya, bukan lafadz așoḥhu (lebih benar). Sikap ini dicontohkan Muhajirin agar para santri dan masyarakat sekitar memahami bahwa pendapat menjadi kuat karena adanya pendukung pendapat lain yang menguatkan. Terminologi aqwā terkesan lebih dinamis dan santun dibanding penggunaan terminologi as่oḥhu (lebih benar). Sikap toleransinya dalam beragama khususnya pada wilayah hukum fikih, jelas tereksplorasi dari teks-teks syarah hadithnya. Sehingga kitab Miṣbāh al-Zalām memiliki keistimewaan dalam menggandeng umat di Indonesia untuk saling menghargai dalam beragama dan berlandasan hukum. Selain itu, memahami hukum fikih lintas madzhab juga mampu menampik mewabahnya Islam radikal dan liberal, dengan harapan menciptakan islam yang lebih dinamis dan harmonis dalam mewujudkan Islām raḥmatan li al- 'alāmīn.

\section{Respon terhadap Dakwah bi al-Qalam Syaikh Muhajirin}

Dakwah bi al-qalam yang digeluti Syaikh Muhajirin semasa hidupnya berperan sebagai media informasi yang memiliki nilai-nilai edukasi untuk dapat merubah kesadaran, membentuk sikap dan merubah perilaku sosial sasaran 
dakwahnya. Kitab-kitab Syaikh Muhajirin memiliki muatan aqidah dan syariah dengan tujuan dapat merubah akhlak mad'unya dengan cara mengajak sasaran dakwahnya untuk melaksanakan perintah Allah dan menjauhi larangan-Nya. Memikul tugas untuk mencegah umat dari perilaku yang menyimpang dari syariat, juga melindungi umat dari pengaruh media massa non-Islam yang anti terhadap Islam. Menurut Dr. Muhammad Aiz dalam wawancara dengan beliau, ${ }^{43}$ Syaikh Muhajirin dalam berbagai tulisanya mencerminkan sebagai sebagai seorang pendidik dengan pemahaman dan penguasaan ilmu agama sangat mendalam dan mampu mentransformasikan ilmunya kepada masyarakat. Sebagai pendidik, Syaikh Muhajirin menjalankan fungsi yang mulia melalui aktivitas dakwahnya di jalur pendidikan, Syaikh Muhajirin sebagai seorang da'i, memiliki sifat sifat 4 karakter Rosul yaitu fathonah, amanah, siddiq, dan tabligh. Sebagai seorang yang mengagumi dan membaca kitab-kitab Syaikh Muhajirin secara berulang-ulang hingga khatam, Dr. Muhammad Aiz menyatakan bahwa kitab Miṣbāh al-Zalām sangat mudah dipahami, karena berbagai penjelasannya selalu disertai dengan contoh-contoh yang kongkrit sesuai dengan keadaaan budaya masyarakat di Indonesia.

Keseluruhan bahasan dalam kitab Miṣbāh al-Ẓalām berisi tentang pandangan-pandangan dari berbagai mazhab tentang suatu permasalahan. Sehingga kesan yang dipahami memberikan nuansa yang mengajarkan tentang sikap toleransi dalam memahami adanya perbedaan pandangan di kalangan para ulama tentang syariat dalam melaksanakan ibadah. ${ }^{44}$ Menurut Dr. Muhammad Aiz, kitab Miṣbāh al-Zalām banyak dipelajari di banyak pesantren sebagai bahan rujukan para ustadz dalam kegiatan dakwah di Mejelis Taklim, khususnya di daerah jakarta dan Bekasi. Dalam hal ini Dr. Muhammad Aiz sendiri menggunakan kitab Miṣbāḥ al-Ẓalām sebagai sumber rujukan yang digunakan dalam kegiatan pengajaran di pesantren.

Metode pengajaran yang diterapkan adalah dengan santri terlebih dahulu ditugaskan untuk membaca dan menganalisis, kemudian jika ada hal-hal yang kurang dimengerti santri lalu beliau menjelaskan dengan contoh-contoh visual yang mudah dimengerti oleh santri. Hal ini merupakan pendekatan pembelajaran kontekstual dengan tujuan agar para santri dapat belajar secara aktif dan kreatif. Implikasi setelah mempelajari kitab Miṣbāh al-Zalām, menurut Dr. Muhammad Aiz, dapat melahirkan keasadaran tentang adanya pandangan yang beragam di kalangan para ulama untuk kemudian dianalisis sehingga pada akhirnya memberikan kesadaran bahwa ajaran Islam itu memiliki makna filosofis yang sangat luas. ${ }^{45}$

KH. Mahfudz Assirun, MA, seorang alumni Pondok Pesantren Annida alIslamy Bekasi sekaligus Pimpinan Pondok Pesantren al-Itqon Jakarta Barat, ${ }^{46}$ menilai gaya pemaparan Syaikh Muhajirin dalam kitab Miṣbāh al-Zalām sangat mudah diterima dan dipahami oleh para Syaikh, asatidz dan jamaah pengajian majelis taklim. Hal tersebut karena kitab Miṣbāḥ al-Zalām menjelaskan secara rinci

${ }^{43}$ Wawancara pribadi penulis dengan Dr. Muhammad Aiz di Pondok Pesantren Annida alIslamy Bekasi (data wawancara terlampir).

${ }^{44}$ Dr. Muhammad Aiz, wawancara pribadi di Pondok Pesantren Annida al-Islamy Bekasi, 16 Januari 2019.

${ }^{45}$ Dr. Muhammad Aiz, wawancara pribadi di Pondok Pesantren Annida al-Islamy Bekasi, 16 Januari 2019.

${ }^{46}$ wawancara pribadi di Pondok Pesantren al-Itqon Jakarta Barat, 28 Januari 2019. (Data terlampir). 
tentang aspek-aspek sayariah dalam ajaran Islam yang berisi tentang fiqih, hadits, aqidah, syariah dan mantiq, sehingga ketika sudah membaca, mempelajari dan menganalisis isi kitab tersebut, akan terbuka cakrawala kesadaran tentang keluasan dan keragaman dalam khasanah intelektual Islam yang ditampilkan dan dikaji oleh para ulama Islam terdahulu.

KH. Mahfud Assirun sendiri mempelajari kitab Misbāḥ al-Zalām sejak tahun 1996 dan menyatakan bahwa dalam kitab Misbāh al-Zalām merupakan sumber inspirasi ijtihad, karena di dalam kitab tersebut mengkaji pendapat para ulama dan imam mzhab terkait dengan berbagai masalah penafsiran terhadap pelaksanaan sholat, dzikir, jinayah, muamalah, dan lain sebagainya dari berbagai tinjauan fiqih dan hadits. Mengaji kitab Misbāh al-Zalām menurut KH. Mahfudz Assirun berimplikasi terhadap adanya perubahan pemahaman dan perilaku dalam kegiatan beribadah dan kegiatan sosial menuju perubahan yang lebih baik. ${ }^{47}$ Begitu pula menurut pandangan KH. Fachrudin, MA, ${ }^{48}$ salah seorang murid dari Syaikh Muhajirin, menyatakan bahwa kitab Miṣbāh al-Ẓalām merupakan kitab wajib yang dijadikan sumber belajar bagi para ustad dan muballig Islam lainnya dikarenakan isinya mudah dipahami, mudah dibaca dan isi kitab tersebut merupakan syarh-syarh dari kitab Bulügh al-Marām karya Ibn Hajar al-Asqolani, yang berisi hadith-hadith ahkam dengan metode pendekatan hukum berpusat pada empat mazhab dan bahkan di luar empat mazhab mu'taber sebagai tampahan informasi.

Menurut KH. Fachrudin MA, kitab Miṣbāḥ al-Zalām mudah dibaca dan dipahami karena dari aspek bahasa menggunakan bahasa Arab fusha yang standar bagi orang Melayu khususnya Indonesia dan tidak banyak menggunakan kalimat musykilat. Konteksnya pun mudah dipahami, sehingga menarik untuk dipelajari dan diteliti. KH. Fachrudin mempelajari kitab Miṣbāḥ al-Zalām sejak tahun 1994 sehingga beliau dapat berkesimpulan bahwa kitab Miṣbāh al-Zalām memilki manfaat yang sangat banyak, selain menambah wawasan, juga memperluas pengetahuan dalam bidang fiqih dan hadith dengan berbagai pendekatan dan berbagai pandangan dari para imam mazhab.

\section{Kesimpulan}

Syaikh Muhajirin tidak hanya pandai berceramah tetapi juga sangat mumpuni dalam hal tulis menulis yang akhirnya menghasilkan sebuah karya. Rangkaian karya-karya yang beliau hasilkan semasa hidup mampu menjadi Pelepas dahaga dan rindu bagi para pencari ilmu dan orang-orang yang mencintai beliau, bahkan jauh setelah kepergian beliau berpulang ke Rahmatullah. Tidak mengherankan jika kemudian kiprah dakwah dan pemikiran yang dikembangkan Syaikh Muhajirin lewat jalur dakwah bi al-qalam dan dakwah bi al-lisan terbukti menjadi suatu oase yang menyegarkan bagi penikmat ilmu-ilmu keislaman, baik yang berstatus sebagai santri maupun bagi masyarakat umum yang senang akan kajian-kajian keislaman.

${ }^{47}$ KH. Mahfudz Assirun, wawancara pribadi di Pondok Pesantren al-Itqom Jakarta Barat, 28 Januari 2019.

48 Wawancara pribadi penulis dengan KH. Fachrudin di Annida al-Islamy Bekasi (Data terlampir). 


\section{Daftar Pustaka}

Aiz, Muhammad. Biografi Muhammad Muhajirin Amsar Addary: Pendiri Pondok Pesantren Annida al-Islamy Bekasi. Bekasi: al-Hanin Press, 2019.

Al-Suyuthi, Tadrib al-Rawi. Beirut: Dar al-Kutub al-Ilmiyah, 2009.

Bek, Ahmad al-Hasyimi. Mukhtaral-Ahadith al-Nabawiyyah, 1367 H /1948.

Bobby Rachman Santoso, Umul Baroroh dan Asep Dadang Abdullah, "Surat sebagai Media Dakwah: Studi atas Praktek Dakwah Rasullah saw terhadap Raja Heraclius, Kisra Abrawaiz, Muqouqis, dan Najasy. "Jurnal Ilmu Dakwah, Vol. 35, No.1 (Januari - Juni 2015).

Brummett. B., Techniques of Close Reading. Los Angeles: SAGE Publication, 2010.

http://annidaalislamy.ac.id/manaqib-pendiri-mahad

https://www.zawiyahjakarta.or.id/2019/09/24/kh-abdul-manaf-mukhayyar/

Majalah ALKISAH, No.12/14, edisi 17 (Juni 2007).

Muchlisin, Badiatul. Berdakwah dengan Menulis Buku. Bandung: Media Qalbu, 2004.

Orderud, Geir Inge. "Is Trust a Driver for Territorially Embedded Industrial Systems? A Case Study of the Home-Building Industry in Norway," Geografiska Annaler, Series B, Human Geography, Vol. 89, No. 4 (2007), h. 341-359. http://www.jstor.org/stable/4621593 (Accessed: 25/02/2014).

Rahim, Husni. Arah Baru Pendidikan Islam. Jakarta: PT. Logos Wacana Ilmu, 2001.

Ratna, Nyoman Kutha. Teori, Metode, dan Teknik Penelitian Sastra dari Strukturalisme Hingga Postrukturalisme: Perspektif Wacana Naratif . Yogyakarta: Pustaka Pelajar, 2004.

Sahli, Mahfudli. Etika Sexuil. Pekalongan : Bahagia, 1989.

Sauda, Limmatus. “Etika Jurnalistik Perspektif al-Qur'an,” Jurnal Esensia, Vol. 15, No. 2 (September 2014).

Wafa, Muhammad Ali. Kiai Muhadjr Amsar; Mercusuar Hadis Nusantara, dalam Islam Nusantara Past and Present. Jakarta; Fakultas Adab dan Humaniora UIN Jakarta, 2014.

Wheller, Brannon M. Prophets in the Quran: An Introduction to the Quran and Muslim Exegesis. Oxford: Continuum Books, 2002.

www.muidkijakarta.or.id

Yunus, Mahmud. Pokok-pokok Pendidikan dan Pengajaran. Jakarta : Pustaka Mahmudin, 1960. 